\title{
AN EXPLORATION OF THE ROLE OF EFL EDUCATORS IN A GLOBALIZED WORLD
}

\author{
Edmund Christopher Melville \\ Dr., Bilkent University, Turkey, emelville.ed@gmail.com
}

\begin{abstract}
The globalization of the 21st century has created questions about and difficulties in the current role of EFL educators because of the many accommodations needed to new cultures, people, and differences in ideologically constructed representations of our roles in terms of culture, class, gender, race, and religion. To address these difficulties, six EFL educators at a private school in Turkey were interviewed for this analytic and auto-ethnographic research to investigate their perceived roles as EFL educators and the relation of these roles to globalization. The theoretical framework was formed from Bourdieu's postcolonial theory and Bhabha's notion of "third space." Interviews, a reflexive journal, and critical incidents were used as means of data collection. The results revealed that EFL educators' hybridity is forced as they navigate this in-between space as products of their prior socialization (i.e., their religious, class, and linguistic capitals). They are simultaneously colonized and colonizers as they "sell" English in Turkey, and they are "border crossers" in the ELT field.
\end{abstract}

Keywords: Globalization, hybrid, English as a Foreign Language (EFL), post-colonial

\section{INTRODUCTION}

EFL education has evolved away from its origins in the colonialism that spread English across the globe; consequently, some of the aims in the adoption of English have changed. Aims for EFL education may now include using English as a bridging language, or "lingua franca" (House 1999), enhancing "global tourism" (MacDonald 2002), and serving "linguistic migration" (Chew 2010). The current era places the globalization of English at the center of the role of EFL educators, regardless of where this expectation comes from. A naturalistic, analytic, auto-ethnographic research methodology was employed for this study in order to answer the general question that guided this study: What relationship as EFL educators do we have to globalization?

Today, EFL educators' decisions are often contextualized by a borderless world. As an EFL educator living and working in Turkey, I agree that globalization affects perceptions of the roles of EFL educators because English is the dominant global language. Sung's (2012, p. 24) research indicates that "in China and India, despite the current economic recession due to the U.S. oriented subprime mortgage and European financial crises in 2007-2008, English is touted as a must if one does not want to lag behind in the fast-changing society and ever-increasing competition in the world." Pennycook (1994) and Holliday (2005) observe that EFL teachers in this era must shift both their social and geographical positions constantly according to their cultural and institutional contexts. According to Pennycook (2007, p. 112), "English is globalization, English is human capital." In this context, both utilitarian and economic rationales for teaching and learning English are usually accepted without a close examination of the historical, sociocultural, and political contexts of the adoption and promotion of English in various regions. 


\section{AN ERA OF GLOBALIZATION}

The term "globalization" often refers to the intensification of capital flows and commodification of relations between states, people, entities, that is grounded in modernization and fueled by the expansion of Western capitalism (Jay 2001). Globalization is also linked to the rise of transnational corporations and the spread of marketplaces across national boundaries, as well as to a rapid deterioration in traditional cultures and disruption in the boundaries of nation-states.

Some researchers, such as Appadurai (1996, p. 7), reject the idea that globalization is synonymous with homogenization or Western domination. He insists that the consumption of mass media and the rapid rise of technology promote virtual travel, which encourages physical travel and thus creates a culture that provides a context for the exercise of power-for "action" rather than "escape". Acar (2004, p. 2) echoes Appadurai's sentiments in terms of "consumption of mass media" as a factor that has played an important role in globalization. He adds that "mobility of populations" owing to "tourism and migration," "transnationalization of markets," and "the end of the cold war that bought a sense of engagement and mission instead of isolationist policies" have also been important factors in the process of globalization.

\section{CULTURAL SABIR AND HYBRIDITY}

Several theories of Bourdieu and of Bhabha can help to shed light on the position of EFL educators in relation to globalization. The "cultural sabir," a concept that arose out of Bourdieu's work in Algeria, were the common people who wished to stand apart from traditional society and adopt certain Western models; two different and even opposing logics are locked in a double-sided expression in all realms of existence (Bourdieu and Sayad 2004). Bourdieu (2004) exemplifies this double approach in his observations of the elders of Algeria, who are the guardians of tradition. These elders viewed the actions of the "cultural sabir" as cultural betrayal. Using this idea, Bourdieu characterized the logic of the colonial situation as producing new types of persons who can be defined negatively twice over: by what they no longer are and by what they have not yet become. Bourdieu's opposing logics are similarly exemplified by Bhabha's (1994, p. 86) sentiment of "white but not quite" which expressed the perception of the self that was created by the colonized attempting to live in the world of the colonizer. There is also an attractive ambivalence about such in-between spaces, indicating that identity is fluid and not fixed.

The merger of two separate and unequal groups, then, creates what Homi Bhabha (1994) called a "third space of enunciation" which expresses new cultural ideas that are first generated and then displaced from the thought of the initial separate groups. This merger of two groups within the third space constitutes hybridity, an idea consonant with Moore-Gilbert's (1997) postcolonial theory, in which he asserted along with Bhabha (1977) that "all forms of culture are continually in a process of hybridity" (p. 129) and that hybridity is a "characteristic predicament of the late twentieth century and early twenty-first century" (p. 195). It is not specific to a colonial or postcolonial context, as Bourdieu and Sayad (2004) attested. The term may also apply to those who seek new positions and placements across social differences-whether in terms of class, race, or gender.

To answer the research question posed earlier-"What is the relationship of EFL educators to globalization?"I began with my own context by interviewing my colleagues at the IPRIS, an English language institute in Turkey, in order to find out how we perceived our roles at IPRIS. In beginning with this specific situation, I hoped to be able to answer the overarching question by generalizing the findings from these interviews.

\section{METHOD}

I chose auto-ethnography as a method of enquiry because, in making sense of one's self, one can also discern how individuals are socialized and shaped by society and culture, and how they are simultaneously guided by their socialized experiences and understandings.

\subsection{Participants}

There were six participants in all: I was the primary participant, and the five secondary participants were surveyed though interviews. I used maximum variation sampling, assuming the existence of the multiple social realities of the participants in addition to my own (Lincoln and Guba 1985). Table 1 provides demographic information for the six participants. 


\begin{tabular}{|c|c|c|c|c|c|c|}
\hline Pseudonym & $\begin{array}{l}\text { Years at } \\
\text { IPRIS }\end{array}$ & $\begin{array}{l}\text { Years } \\
\text { teaching }\end{array}$ & $\begin{array}{l}\text { Country of } \\
\text { origin }\end{array}$ & Gender & Age & $\begin{array}{l}\text { Ethnicity } \\
\text { according to } \\
\text { participant }\end{array}$ \\
\hline Edmund & 6 & 8 & US, & Male & 40 & Black \\
\hline Can & 8 & 12 & Australia & Male & 36 & Turkish \\
\hline Dexter & 6 & 14 & Jamaica & Male & 39 & Black \\
\hline Selen & 10 & 17 & Germany & Female & 45 & Turkish \\
\hline Tabitha & 5 & 30 & $\begin{array}{l}\text { United } \\
\text { States }\end{array}$ & Female & 64 & White \\
\hline Tila & 4 & 8 & Syria & Female & 30 & Syrian \\
\hline
\end{tabular}

\subsection{Data Collection}

Data collection occurred in three successive phases: (1) orientation and overview, (2) focused exploration, and (3) member checks and closure.

For the first phase, I drew on my own experience by keeping a "reflexive journal" (Lincoln and Guba 1985, p. 266). In the second phase of data collection, I focused by conducting two semi-structured, 45-minute interviews with each of the secondary participants to collect data. The third phase of data collection began with the second round of interviews and ended with the member check.

\section{FINDINGS AND DISCUSSION}

Several commonalities emerged from the interviews. In exploring the participants' view of English as a global language, it became clear that all of us had been obliged to reflect on the very thread that binds us as professionals. Kramsch (1999, p. 138) observed that "[i]f there is one thing that globalization has bought us, and that the teaching of English makes possible, it is travel, migration, multiple alliances and a different relationship to time and place." As EFL educators, Canagarajah (2012) notes, we cannot sustain ourselves as a homogeneous profession with a centralized organization anymore. This change in perspective is crucial because the English language defines us as professionals and is central to our livelihoods. The participants all agreed, in one way or another that the role of English is to represent "the global as well as the local, which often permeate each other" (Canagarajah 2012, p. 262).

As a major signal of the changes participants had observed, almost all of them used the word "now" multiple times in speaking of English as a global language. Can, for example, observed,

English is the language of the world. I mean, English is now becoming very important as we progress in time; English is now becoming like a staple language in countries. We've always had this notion that a second language is beneficial; now you must know your mother tongue and English. English is a given. You have to know English. (Can, first interview, 2 December 2013)

Can clearly perceive the role of English as a global language, his comments also revealing his relationship to globalization, first, because he uses "now" to represent the era of globalization. Second, his comments agree with findings from Sung (2012), who found that English is touted as a must if one does not want to lag behind in the fast-changing society and ever-increasing competition in a globalized world. Can explained further: "I think the reason for this is ... that there are more and more countries now where English is the common language ... used ... for communication." Can explicitly identified the role of English also in terms of the global "now" when he observed, "I see the role of English in the world as the bridge language, and it's more and more a language which you must know now" (Can, second interview, 20 December).

According to House (1999), when two or more different people, none of whom have English as the mother tongue, choose English as a bridge for communication, the role of English becomes the lingua franca. Tabitha, who is from the United States, indicated that she views English as the current lingua franca when she remarked,

I think that now the role of English as a global language has a lot to do with the tourism industry. I was just in the Netherlands and Tanzania, and I was surprised how all of the workers spoke English. But maybe it's because of the British, who were so out in the world, I mean well... the British were the world power for such a long time...everywhere I visit, they don't ask if we're Americans. They ask if we're English. 
Tabitha's comments, like Can's, suggest her perspective on globalization in two ways: she had been surprised at her ability to use English as a lingua franca when she visited both the Netherlands and Tanzania. Second, when Tabitha alluded to "the British ... as the world power for such a long time," she was referring to the British imperialism that spread the English language throughout its colonies. In mentioning British imperialism, Tabitha implies, as McLaren and Farahmandpur (2001) argue, that "globalization" has effectively replaced "imperialism" in the vocabulary of the privileged class.

Thus, both Can's and Tabitha's remarks reveal that English is viewed the world over as the dominant language. Al-Jarf (2008), who researches and teaches in Saudi Arabia, likewise showed that $96 \%$ of the participants in a study she conducted considered English superior to Arabic. The participants in Al-Jarf's study felt it was imperative to learn English because the world has become a small village in which English is the dominant language. In reflecting on the role of English as dominant, we must also consider Bourdieu's argument that "the social structure of a given field is premised upon dominant and subordinate positions" (Bourdieu and Wacquant 1992, p. 97). Perhaps the consideration of English as "superior" and/or "dominant" results from people's perception of their positioning vis a vis their knowledge of English in this global village.

Tila, who is from Syria and whose mother tongue is Arabic, held views similar to Can's regarding the role of English as a global language, but whereas Tabitha regarded England as the major player, Tila looked instead to the United States, again referring to the global "now" and indicating that a shift has taken place:

The US is politically the strongest country now, so you have an advantage. And as history has shown us, if a country's language is politically strong, that country's language will most probably prevail, and English is a perfect example. As we see, if the English-language speaking country is politically strong, the language also dominates. (Tila, first interview, 29 November 2013)

Tila also hints at her relationship to globalization when she says "as history has shown us" and "if the Englishlanguage speaking country is politically strong, the language also dominates"; here, her words implicate Robertson's (1990) argument that globalization is not merely a contemporary event; he recognizes that it has a long history. Tila's mention of the political strength of English-speaking countries also invokes Bourdieu's notion that the "dominance of language forms is ultimately related to the power structure of a society" (Finlayson 1999, p. 58).

Selen, while echoing the others' view of the role of English as a global language, brought up another aspect: that the use of English imposes a kind of cultural imperialism. She appeared hesitant to link her political views with the English language, but she said, "Now, English has become the world's language. I do not want to put in my political views, but obviously, it is imperialism as well, in that regard, in that while you spread your language, you spread your culture as well. Just look at IPRIS; we nicknamed this place Little America." Selen's explanation demonstrated both affinity and resentment as she said, "Here in Turkey, you have to know English; it is a requirement if you want to be successful. ... [A]ll of the research and technological advancements are from the West."

In such circumstances, native English speakers are often preferred, employment-wise, as teachers over those for whom English is truly a second language. In a study of non-native EFL educators, for example, Ozturk and Atay's (2010) study revealed that all of the participants viewed native speakers (e.g., from the US or UK) as being "much more welcome" in Turkey than Turkish EFL educators. Participants in that study made comments like "native speakers don't need to be ELT graduates" and "for them being native is enough" (Ozturk and Atay 2010, p. 137). All of the participants in that study had been rejected for employment at Turkish English medium private schools. Remembering that Bourdieu (1993, p. 72) defined fields as "arenas of struggle for control over valued resources or forms of capital," Tila's and Selen's comments, in agreement with the findings from Ozturk and Atay's study, provide concrete examples of a struggle for valued resources, which is the struggle over economic capital.

In her second interview, Tila mentioned yet another aspect of English as a global language when she observed, "... [E]ven technology-wise, English is the universal language now. Let's say a product is invented in Japan; the labels are translated into English not only for the US and the UK but also for many countries around the globe" (Tila, second interview, 20 December 2013).

Tila's comments on how she views the role of the English language directly related to Dexter's, who said, "Now, there are so many things that you can do with technology in terms of communication. With English, you can make an instant connection anywhere in the world that would take you maybe weeks or months a generation or two earlier." MacDonald (2002, p. 1-2) similarly alludes to the fact that "...the technologies of 
globalization that annihilate socio-spatial distance insert us into webs of relationships with individuals and communities that are unknown to us in any corporeal way."

It is an open question as to whether this "web of relationships" extends in any meaningful way to the individual. Tila, in questioning my interests, did not reflect a "web of relationships" with me as an individual:

OK, we have spoken about how I view the role of English as a global language. Let's talk about how you see the role that the English language plays across the globe.... I know that in Syria, Lebanon, and many other Arabic countries, you need to know English. But Spanish is also spoken all over the world, and we are not sitting here speaking about Spanish. My question for you is [this]: aren't you only interested because of the economic and political power that English has? Isn't that the reason that that you are interested in the role that English plays as a global language? (Tila, second interview, 20 December 2013)

Tila's pointed question, "[A]ren't you only interested because of the economic and political power that English has?" evoked some discomfort. I responded as honestly as I could by explaining that I indeed did not see a separation between "the economic and political power a language has" and the fact that English is the "most sought after foreign language" today. Pennycook (2007, p. 112) wrote that EFL educators provide English education as the "global commodity." Similarly, Bourdieu (1991) has discussed the commodification of language where ELT is referred to as a "linguistic market." As in any market, there are "monopolies in the markets of linguistic goods" (Bourdieu 1992, p. 147). It is possible that I, as an American EFL educator, represent that "monopoly" to Tila, which may have been why her tone was accusatory.

In Bourdieu's "linguistic market," then, the speakers themselves (in this case, the EFL educators) are assigned values. We may conceptualize ELT as a field (an arena of struggle) that has a linguistic market, wherein EFL educators are considered to possess different amounts of linguistic capital. The amounts of linguistic capital (i.e., accents and native or non-native varieties of English) determine the value EFL educators have, depending on the ideology of the country's and school's culture (Finlayson 1999). Such a situation is what Bourdieu termed symbolic violence, "which is exercised upon a social agent with his or her complicity" (Bourdieu and Wacquant 2002, p. 167). In this sense, EFL educators are complicit because there are other options for work. In sum, in the ELT field, the role of English as a global language constructs an arena in which different linguistic representations (different forms of English) are used to compete for symbolic, social capital (i.e., recognition and praise for a job well done) as well as economic capital.

To summarize, although all of the participants in this study clearly stated their perception of the role of English as a global language, their contrasting and sometimes contradictory views still represent the field, in Bourdieu's terms, as an arena of struggle. For us ELT teachers at IPRIS in Turkey, English as the global language separates and binds us. It separates us in terms of how we are positioned as non-native or native EFL educators. It binds us in that our use of the English language in context is the shared tool that sustains us with relation to our social, cultural, political, and economic needs.

\section{CONCLUSION}

Interestingly, most of the participants (Dexter, Selen, Can, Tila, and I) come from frequently undervalued positions in terms of race and nationhood (see Table 1). We are, in many ways, the "cultural sabir"; our hybridity is forced because we must navigate an in-between space as products of our prior socialization (including our religious, class, and linguistic capitals). We are simultaneously colonized and colonizers as we collectively work at a private institution that "sells" English in Turkey in a "linguistic market" (Bourdieu 1991); thus to some extent, we, along with the language we "sell," have become commodities in our globalized world. Further, we are "border crossers" (Howey and Zimpher 2006) in the ELT field. We are social agents whose very different habitus (es), forged by a wide range of capitals, mediate our actions and interactions in this field and hybridize our roles as EFL educators. Hence, all of the participants in this study embody/represent hybridity - that is, the cross-cultural. English has become the language of the world, the linguistic capital that allows movement and flexibility; it allows the opportunity to become someone different. The English language itself then presents an opposing logic, being both negative and positive because it enables both freedom and constraint. In sum, EFL educators are perhaps both agents for and products of globalization.

\section{REFERENCES}

Bourdieu, P. (1991). Language and Symbolic Power. Cambridge, England: Polity. 
Bourdieu, P. \& Wacquant, L. J. D. (1992). An Invitation to Reflexive Sociology. Chicago, IL: University of Chicago Press.

Canagarajah, S. (2012). "Teacher Development in a Global Profession: An Auto ethnography". TESOL Quarterly. 46 (2). P. 258-279.

Chew, P. G. L. (2010). "Linguistic Capital, Study Mothers and the Transnational Family in Singapore". In Vaish, V. (ed.). Globalization of Language and Culture in Asia: The Impact of Globalization Processes on Language. London, England: Continuum. P. 82-106.

Finlayson, A. (1999)" Language”. In Ashe, F., Finlayson, A., Lloyd, M., MacKenzie, I., Martin, J. \& O’Neill, S. (eds.). Contemporary Social and Political Theory: An Introduction. Buckingham, England: Open University Press. P. 47-68.

House, J. (1999) "Misunderstanding in Intercultural Communication: Interactions in English as a Lingua Franca and the Myth of Mutual Intelligibility". In Gnutzmann, C. (ed.). Teaching and Learning English as a Global Language. Tübingen, Germany: Stauffenburg. P. 73-89.

Howey, K. \& Zimpher, N. (2006) Boundary Spanners: A Key to Success in Urban P-16 University-schools Partnerships. Washington, DC: American Association of State Colleges and Universities.

Kramsch, C. (1999). "Global and Local Identities in the Contact Zone". In Gnutzmann, C. (ed.). Teaching and Learning English as a Global Language. Native and Non-native Perspectives. Tubingen: Stauffenburg Verlag, p. 131-143.

MacDonald, K. I. (2002). "Epistemic Violence: The Body, Globalization and the Dilemma of Rights". Transnational Law and Contemporary Problems. 12 (1). P. 65-87.

Ozturk, U. \& Atay, D. (2010). "Challenges of Being a Non-Native English Teacher". Educational Research. 1 (5). P. 135-139

Pennycook, A. (2007). "The Myth of English as an International Language". In Makoni, S. \& Pennycook, A. (eds.). Disinventing and Reconstituting Languages. Clevedon: Multilingual Matters. P. 90-115.

Robertson, R. (1990). "Mapping the Global Condition: Globalization as the Central Concept". Theory, Culture and Society. 7 (2). p. 15-30. 